\title{
Phlebotomine fauna (Diptera: Psychodidae) of an American cutaneous leishmaniasis endemic area in the state of Mato Grosso do Sul, Brazil
}

\author{
Maria Elizabeth C Dorval' ${ }^{1+}$, Geucira Cristaldo', Hilda Carlos da Rocha', Tulia Peixoto Alves ${ }^{1}$, \\ Murilo Andrade Alves', Elisa Teruya Oshiro', Alessandra Gutierrez de Oliveira', \\ Reginaldo Peçanha Brazil ${ }^{2}$, Eunice Aparecida Bianchi Galati ${ }^{3}$, Rivaldo Venâncio da Cunha ${ }^{4}$
}

\begin{abstract}
${ }^{4}$ Departamento de Clínica Médica ${ }^{1}$ Departamento de Patologia, Universidade Federal de Mato Grosso do Sul, CP 549, 79070-900 Campo Grande, MS, Brasil ${ }^{2}$ Laboratório de Bioquímica e Fisiologia de Insetos, Departamento de Bioquímica e Biologia Molecular, Instituto Oswaldo Cruz-Fiocruz, Rio de Janeiro, RJ, Brasil ${ }^{3}$ Departamento de Epidemiologia, Faculdade de Saúde Pública, Universidade de São Paulo, São Paulo, SP, Brasil
\end{abstract}

The occurrence of an outbreak of cutaneous leishmaniasis associated with Leishmania (Leishmania) amazonensis in the municipality of Bela Vista, state of Mato Grosso do Sul, Brazil, and the absence of information on its vectors in this area led the authors to undertake captures of phlebotomine sand flies, using Shannon traps and automatic CDC light traps, in domiciles, forested areas and animal shelters from February 2004-January 2006. A total of 808 specimens belonging to 18 sandfly species have been identified: Bichromomyia flaviscutellata, Brumptomyia avellari, Brumptomyia brumpti, Brumptomyia sp, Evandromyia aldafalcaoae, Evandromyia cortelezzii, Evandromyia evandroi, Evandromyia lenti, Evandromyia teratodes, Evandromyia termitophila, Lutzomyia longipalpis, Nyssomyia whitmani, Pintomyia christenseni, Psathyromyia aragaoi, Psathyromyia campograndensis, Psathyromyia punctigeniculata, Psathyromyia shannoni and Sciopemyia sordellii. The presence of Lu. longipalpis, Ny. whitmani and $\mathrm{Bi}$. flaviscutellata, vectors of Leishmania chagasi, Leishmania braziliensis and $\mathrm{L}$. amazonensis, respectively, has increased.

Key words: Phlebotominae - Psychodidae - leishmaniasis - Mato Grosso do Sul - vectors

The leishmaniases are currently regarded as a serious public health issue in affected areas, especially due to the rapid processes of expansion and urbanisation (Desjeux 2004). In Mato Grosso do Sul (MS), Brazil, visceral leishmaniasis (VL), which was reported for the first time by Migone in 1913, has spread quickly; it is currently reported as an endemic disease with notification in 49 municipalities, especially those on highway BR 262 (SSMS 2008). American cutaneous leishmaniasis (ACL), which affects 72 out of the 78 municipalities in MS, still occurs due to anthropic actions, afflicting primarily males at the productive age and farm labourers (Nunes et al. 1995, Nunes 2001).

The recent identification of Leishmania (Leishmania) amazonensis as an etiological agent of an ACL outbreak affecting individuals in a military training unit in the municipality of Bela Vista (Dorval et al. 2006) led the authors to investigate the phlebotomine fauna in that area, with the report of this investigation being the object of the present paper.

Financial support: FUNDECT/DECIT (00645-03), UFMS

+ Corresponding author: mecdorval@gmail.com

Received 5 December 2008

Accepted 30 April 2009

\section{MATERIALS AND METHODS}

Study area - The municipality of Bela Vista $\left(22^{\circ} 06^{\prime}\right.$ $32^{\prime \prime} \mathrm{S} 56^{\circ} 31^{\prime} 16^{\prime \prime} \mathrm{W}, 180 \mathrm{~m}$ asl) is located in the southwestern region of MS, in the geographical micro-region of Bodoquena. It has an area of $5,315 \mathrm{~km}^{2}$ and its borders are: the municipality of Jardim northwards, the Republic of Paraguay southwards, the municipality of Antônio João eastwards, and the municipality of Caracol westwards. Bela Vista is located on the right bank of the River Apa, opposite the Bella Vista district in Paraguay, $349 \mathrm{~km}$ from the state capital, Campo Grande (SMS 2001).

Of the original vegetation that covered the region, savannah-like formations, seasonal forests and savannah predominate and only a few seasonal semideciduous forest-like formations were preserved. Currently, $80 \%$ of the total area is occupied by agriculture (temporary crop husbandry) and cattle raising activities (native and cultivated pastures) (IBGE 2002).

Local characteristics - The $10^{\circ}$ Regimento de Cavalaria Mecanizado $\left(10^{\circ} \mathrm{RCMec}\right)$, located in the municipality of Bela Vista, has an area with heterogeneous vegetation represented by areas of campo sujo, forested savannah (cerradão), gallery forest and marsh, all of them significantly marked by human presence.

Some places situated close to the Candelão stream are floodable areas with unusual gallery forest-like vegetation, where pioneer and secondary species are predominant, distorting the surroundings of the remaining 
woods. There is a large quantity of sand and waste carried into the stream, resulting in the formation of vegetation banks with invasive species. In other areas, arborous strata with deciduous species predominate, which allows organic material to accumulate as a result of the decomposition of leaves and vegetation waste lying on the soil. In the area called Granja, there are two uninhabited houses, a pigsty and a semi-abandoned hen-house. Its surroundings consist of a riparian wood, followed by a swamped area with herbaceous and bush-like vegetation, although the spread and growth of species regarded as invaders of open areas may also be noted.

Captures with automatic light traps - From February 2004-January 2006, 14 CDC automatic light traps (Natal et al. 1991) were installed at ground level $(1 \mathrm{~m})$ and on the tree canopy $( \pm 3 \mathrm{~m})$ throughout the area used for military instruction activities. Eight environments were selected according to how often they were used and how long the military remained there during the training period: Pista de corda (Rope Site), Pista de Primeiros Socorros (First Aid Site), Base do Primeiro Esquadrão (First Division Headquarters) and Áreas de Acampamento [Camping areas (1 and 2)].

Domestic animal shelters on the Regimento premises were also sampled: a hen house, a pigsty and the horse stalls. The catches were carried out on a fortnightly basis, from 6 pm until 6 am, disregarding the summer time change.

During the second year of the study, two other houses were included: one located in the centre of the town, $2 \mathrm{~km}$ from the capture area, and another located inside the Military Villa, close to the Regimento, about $300 \mathrm{~m}$ from this area.

Captures with Shannon traps - In the so-called First Division Headquarters, the researchers performed monthly captures with white and black Shannon traps (Galati et al. 2001) lit by a cold white light driven by a 12-volt battery, with two collectors capturing over a period of $6 \mathrm{~h}$ (commencing at $6 \mathrm{pm}$ and ending at midnight). Twelve-hour-long captures were also carried out (from $6 \mathrm{pm}$ until $6 \mathrm{am}$ ) on a seasonal basis.

The insects were caught in individual flasks and maintained in a pottery recipient coated with humid clay until the assays could be performed in the Regimento laboratory. All females were dissected and had their digestive tract and genitalia exposed for analysis of natural infection and specific identification, respectively. The male specimens were identified after clarification and slide mounting. The specific terminology used followed Galati's (2003).

Statistical analysis - The standard abundance index (SISA) was calculated according to the method defined by Roberts and Hsi (1979). Williams's geometric average (Haddow 1960) was used to quantify the frequency of some data. Shannon and Pieloux indices were used to estimate the diversity and regularity of species, respectively (Hayeck \& Buzas 1997).

Due to the non-existence of meteorological data in the town, climate records from the Meteorological Station of the Airport of Ponta Porã, MS (Superintendência Regional do Sudeste/Gerência de Navegação), located approximately $100 \mathrm{~km}$ from Bela Vista, were used.

\section{RESULTS}

The sandfly fauna captured belonged to eight genera and 18 species: Bichromomyia flaviscutellata, Brumptomyia avellari, Brumptomyia brumpti, Brumptomyia sp, Evandromyia aldafalcaoae, Evandromyia cortelezzii, Evandromyia evandroi, Evandromyia lenti, Evandromyia teratodes, Evandromyia termitophila, Lutzomyia longipalpis, Nyssomyia whitmani, Pintomyia christenseni, Psathyromyia aragaoi, Psathyromyia campograndensis, Psathyromyia punctigeniculata, Psathyromyia shannoni and Sciopemyia sordellii.

In all the environments sampled, 354 phlebotomine sand flies were caught using automatic light traps. There were 194 males $(54.80 \%)$ and $160(45.20 \%)$ females and the male/female ratio for all species was 1.2:1.0. The total number of insects caught according to the environment, trap level, sex and the respective diversity and evenness indices in each sampled site are shown in Table I. The SISA is shown in Table II.

Considering all the environments studied and the overall number of sandflies caught, the predominant species were Br. brumpti $(31.36 \%)$ and Lu. longipalpis $(29.94 \%)$, followed by Ev. lenti (13.28\%) and Br. avellari (11.86\%).

The index of diversity in the forested area was higher (1.2-1.8) than in the animal shelters (0.1-1.4), thus yielding a higher number of species, but presenting, for the most part, low frequencies. The lowest diversity index was observed in horse stalls, with only two species captured.

The SISA showed that the most abundant species, present in all environments, was $E v$. lenti $(\mathrm{SISA}=0.792)$, followed by Br. brumpti (SISA $=0.694$ ) and $B r$. avellari (SISA $=0.625$ ), with SISA values closer to 1.0 , indicating maximum abundance and occupation of a larger number of ecotopes.

The most abundant species in the forested area were Br. brumpti (SISA $=1.00)$, Br. avellari $(\mathrm{SISA}=0.856$ ) and $E v$. lenti (SISA $=0.689$ ), with the first showing maximum abundance, whereas in the animal shelters the most frequent species were Ev. lenti $($ SISA $=0.933)$ and Lu. longipalpis (SISA $=0.867)$ (Table II).

For intradomiciliar captures, six males and seven females of Lu. longipalpis were caught in the military house and in the house in the centre of town; the species found were Ev. aldafalcaoae (one male and one female ) and Lu. longipalpis (26 males and 9 females).

With Shannon traps, in addition to fauna similar to that obtained with automatic light traps, Ev. cortelezzii and Ev. teratodes were also caught. The 454 specimens captured monthly with this kind of trap belonged to the 14 species presented in Table III; there were 206 males (45.37\%) and $248(54.63 \%)$ females, with a female/male ratio of 1.2:1.0. No specimens of sandflies were caught in the black traps.

Williams's geometric average, which indicates both the quantity and frequency of insects caught in the traps, was calculated for the total number of male and female specimens captured monthly in Shannon traps (Fig. 1). The highest means were found in July, August and September, coinciding with the least rainy season. Fig. 2 shows the accumulated rainfall, the average monthly 


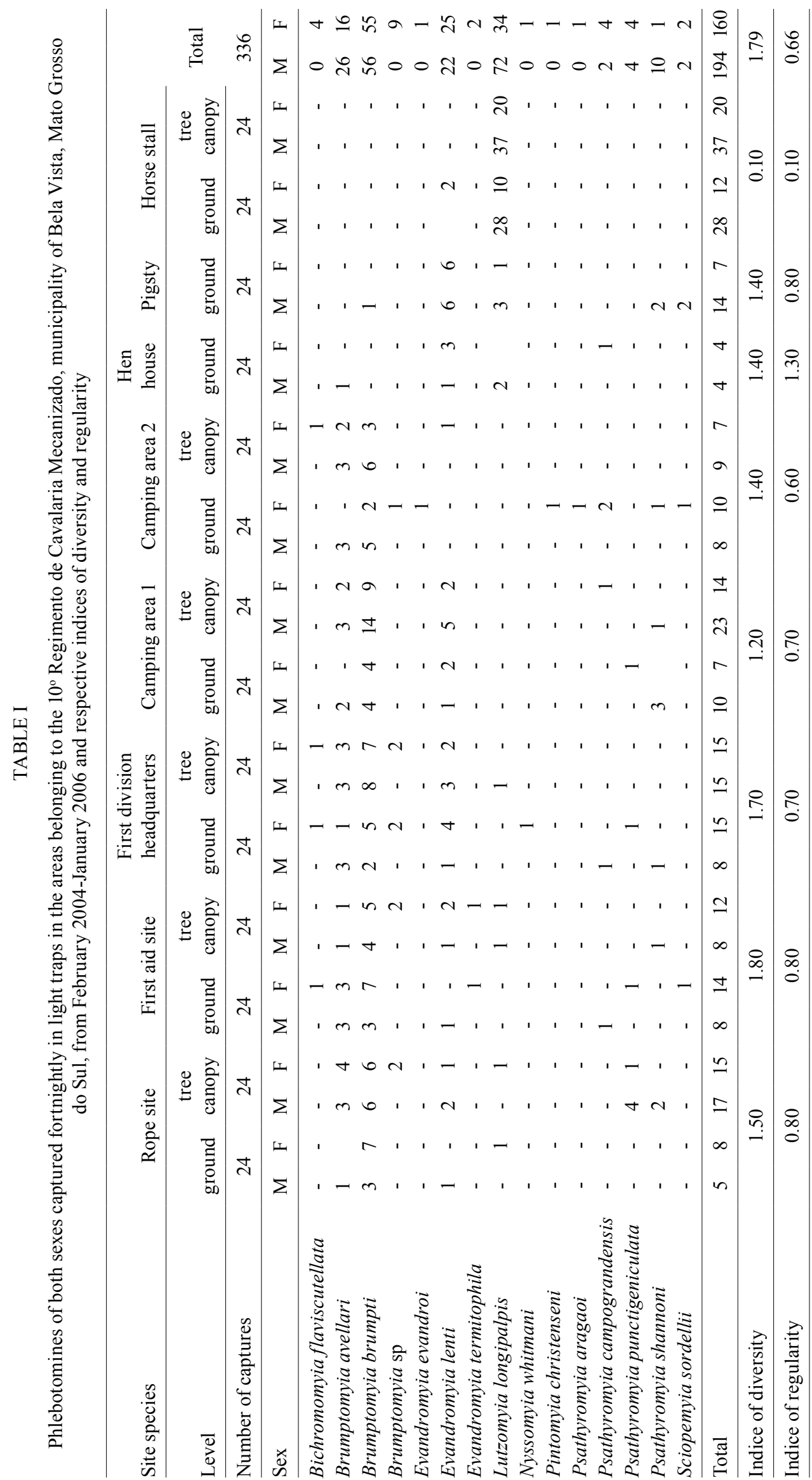




\section{TABLE II}

Standard index of species abundance (SISA) for phlebotomines captured with automatic light traps in forested areas and in domestic animal shelters of the $10^{\circ}$ Regimento de Cavalaria Mecanizado, municipality of Bela Vista, Mato Grosso do Sul, from February 2004-January 2006

\begin{tabular}{|c|c|c|c|c|c|c|}
\hline \multirow[b]{2}{*}{ Species } & \multicolumn{2}{|c|}{ Woods } & \multicolumn{2}{|c|}{ Animal shelters } & \multicolumn{2}{|c|}{ Total } \\
\hline & SISA & Position & SISA & Position & SISA & Position \\
\hline Bichromomyia flaviscutellata & 0.189 & $8^{a}$ & - & - & 0.118 & $10^{a}$ \\
\hline Brumptomyia avellari & 0.856 & $2^{a}$ & 0.200 & $5^{a}$ & 0.625 & $3^{a}$ \\
\hline Brumptomyia brumpti & 1.000 & $1^{a}$ & 0.067 & $3^{a}$ & 0.694 & $2^{a}$ \\
\hline Brumptomyia sp & 0.378 & $4^{a}$ & - & - & 0.243 & $7^{a}$ \\
\hline Evandromyia evandroi & 0.056 & $11^{a}$ & - & - & 0.035 & $12^{a}$ \\
\hline Evandromyia lenti & 0.689 & $3^{a}$ & 0.933 & $1^{a}$ & 0.792 & $1^{a}$ \\
\hline Evandromyia termitophila & 0.111 & $9^{a}$ & - & - & 0.069 & $11^{a}$ \\
\hline Lutzomyia longipalpis & 0.233 & $7^{a}$ & 0.867 & $2^{a}$ & 0.500 & $4^{a}$ \\
\hline Nyssomyia whitmani & 0.044 & $12^{a}$ & - & - & 0.028 & $13^{a}$ \\
\hline Pintomyia christenseni & 0.056 & $1^{a}$ & - & - & 0.035 & $12^{a}$ \\
\hline Psathyromyia aragaoi & 0.056 & $1^{a}$ & - & - & 0.035 & $12^{a}$ \\
\hline Psathyromyia campograndensis & 0.322 & $6^{a}$ & 0.167 & $4^{a}$ & 0.292 & $6^{a}$ \\
\hline Psathyromyia punctigeniculata & 0.322 & $6^{a}$ & - & - & 0.201 & $8^{a}$ \\
\hline Psathyromyia shannoni & 0.333 & $5^{a}$ & 0.167 & $4^{a}$ & 0.306 & $5^{a}$ \\
\hline Sciopemyia sordellii & 0.078 & $10^{a}$ & 0.167 & $4^{a}$ & 0.139 & $9^{a}$ \\
\hline
\end{tabular}

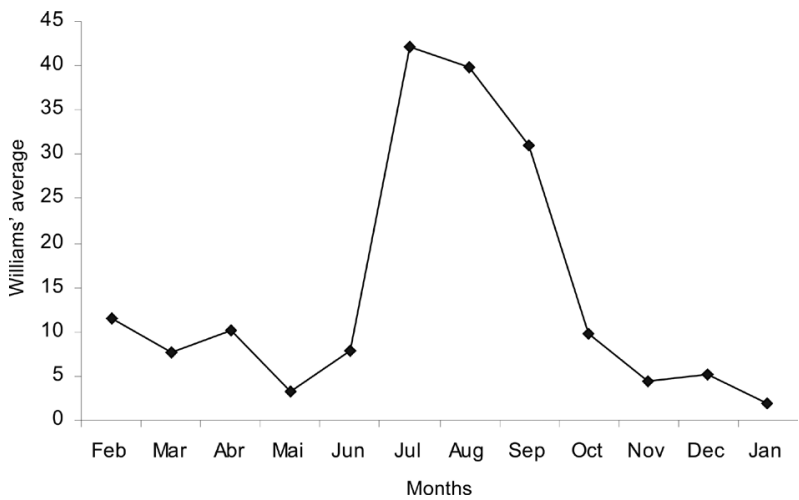

Fig. 1: monthly average of both sexes of phlebotomine species captured in Shannon traps in the $10^{\circ}$ Regimento de Cavalaria Mecanizado, municipality of Bela Vista, Mato Grosso do Sul, from February 2004-January 2006.

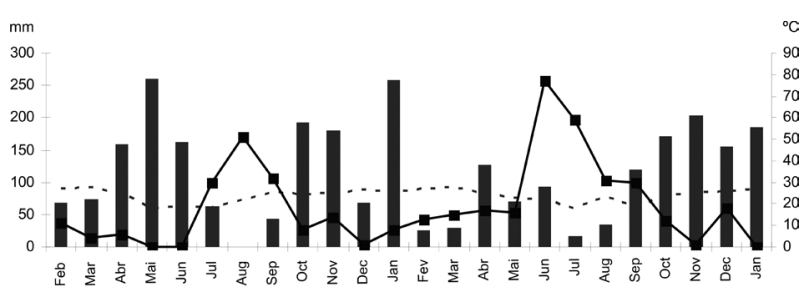

Fig. 2: monthly rainfall, average temperature and number of phlebotomines of both sexes captured monthly in Shannon traps in the $10^{\circ}$ Regimento de Cavalaria Mecanizado, municipality of Bela Vista, Mato Grosso do Sul, from February 2004-January 2006. temperature and the total number of insects of both sexes caught over two years.

In this kind of trap, species Ps. shannoni (34.58\%), Ps. punctigeniculata $(21.59 \%)$ and Ev. lenti (14.32\%) accounted for $70.49 \%$ of the specimens caught, followed by $\mathrm{Br}$. brumpti (8.81\%), Bi. flaviscutellata (5.95\%), Lu. longipalpis (4.41\%) and Br. avellari (5.95\%). Among the females, Ps. puncigeniculata (33.9\%) predominated, followed by Ps. shannoni (17.3\%).

Fig. 3 shows the average number of specimens caught per hour for each species and the predominant species caught over the first three hours of capture. The catches made after midnight were not included in the analysis and graphs because the number of captures after this hour was not significant; only six specimens were caught, including Ps. shannoni (3 specimens), Br. brumpti (2 specimens) and Ps. punctigeniculata (1 specimen). Fig. 4 shows the hourly averages for the most abundant and most frequent species, Ps. shannoni and Ps. punctigeniculata.

Except for S. sordellii, which in the present study was found to be infected by a large number of flagellates with no specific identification thus far, all other females dissected were negative for flagellates based on inspection by optical microscopy.

\section{DISCUSSION}

The presence of 18 phlebotomine species in the studied area, even at low frequencies, shows a diversified fauna as previously reported in the state (Galati et al. 1996, 1997, 2003a, b, 2006, Oliveira et al. 2003). These findings highlight the research performed by Galati 


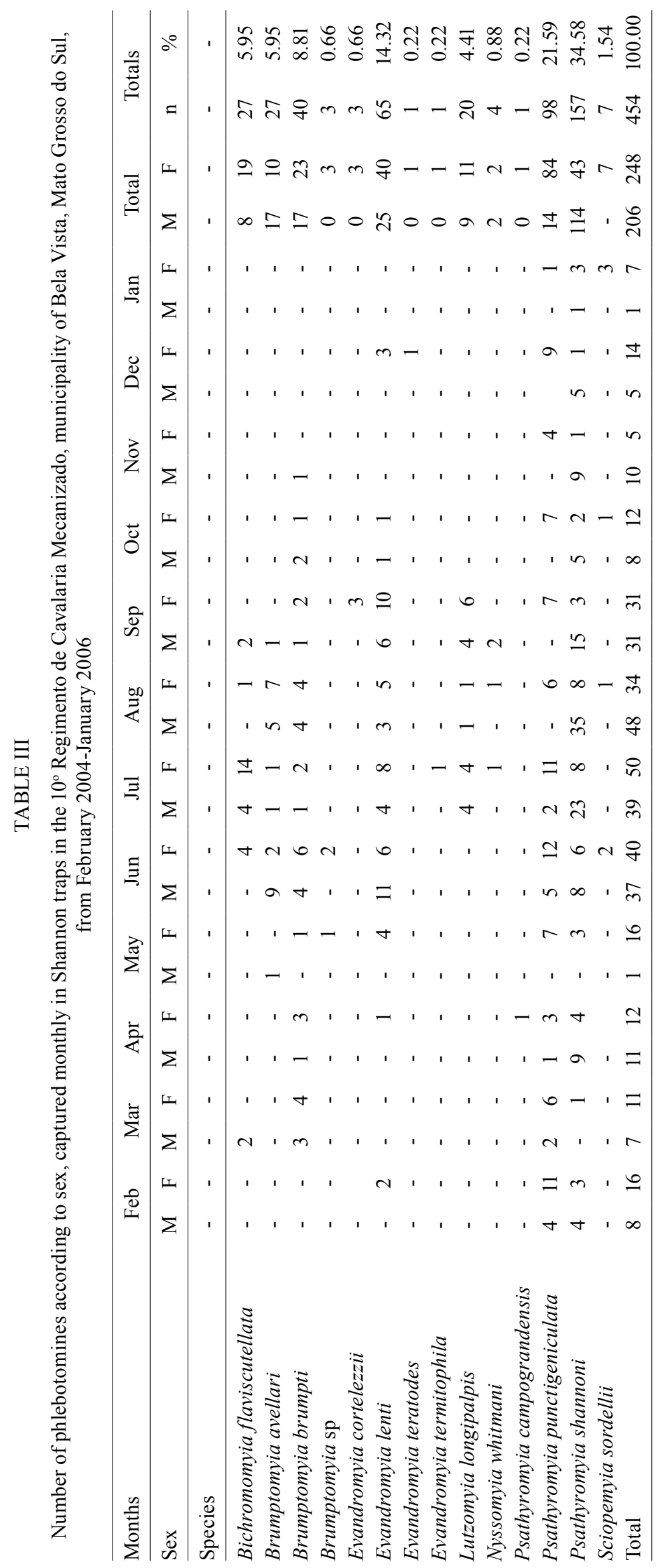




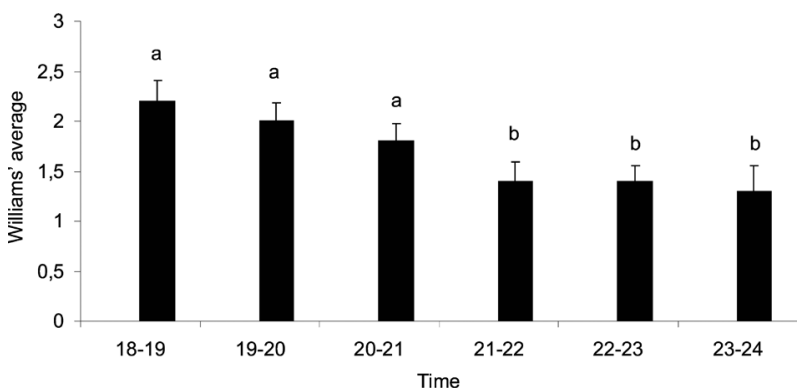

Fig. 3: Williams' hourly average and standard deviation for both sexes of phlebotomine species captured monthly in Shannon traps in the $10^{\circ}$ Regimento de Cavalaria Mecanizado, municipality of Bela Vista, Mato Grosso do Sul, February 2004-January 2006. Different letters between lanes represent significant statistical difference $(p<0.05)$.

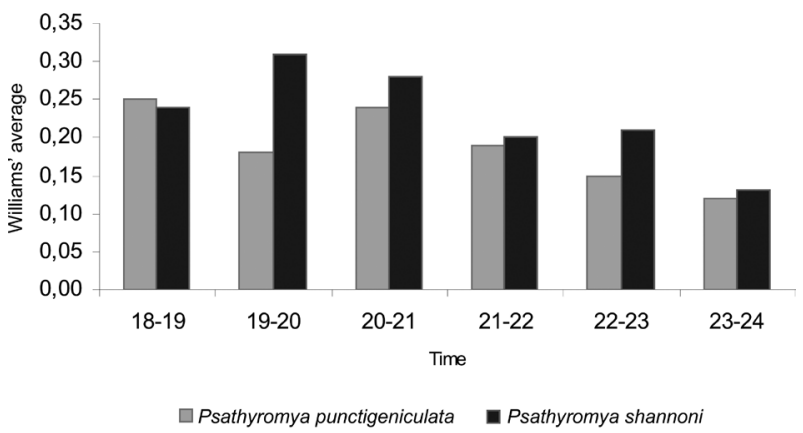

Fig. 4: Williams' hourly average for both sexes of the most abundant species captured monthly in Shannon traps in the $10^{\circ}$ Regimento de Cavalaria Mecanizado, municipality of Bela Vista, Mato Grosso do Sul, February 2004-January 2006. et al. (2003b) on foci of ACL in Bodoquena, in whose southwestern region Bela Vista is located.

It is noteworthy that sandflies were not drawn to the black traps in the area, which is not compliant with the findings of Galati et al. (2001) in the Serra da Bodoquena, where such traps were used more efficiently.

As for the phlebotomines' nocturnal habits, the highest concentration of specimens occurred between 6-9 $\mathrm{pm}$. Thus, the exposure of people visiting the area of study should be reduced during this period, when the risk of leishmaniasis transmission is highest.

On the whole, the sandflies of the study area were caught throughout the year, but the highest density occurred during the driest season, when temperature ranged from $18.2-25^{\circ} \mathrm{C}$. Thus, the pattern of species abundance over the two years of study seems to point out that the driest season is the most favourable to the adult activity of most species.

Brumptomyia species are broadly distributed in America (Martins et al. 1978) and constitute the group of sandflies commonly associated with armadillo burrows. They were not abundant in the caves and forested areas of the Serra da Bodoquena studied by Galati et al. (2003a, 2006), nor in a cave situated in the Pantanal region(Galati et al. 1997). In the present study though, they were present with high frequency $(48.3 \%)$ in the light traps installed in the woods. In Shannon traps, $15.4 \%$ of specimens captured were Brumptomyia, which suggests that, unlike the environments sampled by the previously mentioned researchers, this forest soil is favourable to the development of these sandflies and that these insects are also highly attracted to light. It is noteworthy that the efficiency of the Shannon traps is influenced by human attraction and also by light.

$E v$. lenti was the most abundant species in the area, present in several environments studied and was shown to be highly attracted to Shannon traps. It has already been reported in pigsties, perches and savannah areas in MS (Galati et al. 1996) and is also one of the most frequently found species in the urban peridomiciles of the capital, Campo Grande (Oliveira et al. 2003), and in many other towns in the state of Goiás, where a significant association of this species with cases of ACL was observed (Martins et al. 2002).

As noted by Galati et al. (2003b), Lu. longipalpis, a species of recognised importance in VL transmission in Latin America, showed poor attraction to Shannon traps. It was present though, accounting for $29.9 \%$ of the specimens collected with CDC traps and frequently found in horse stalls located on the premises of the $10^{\circ} \mathrm{RCMec}$.

Such a result is compliant with the literature data, which report a high frequency of this sandfly in anthropic environments and in animal shelters (Azevedo et al. 2000). According to Ximenes et al. (1999), among all the specimens collected in horses, $95 \%$ were $L u$. longipalpis. In the Serra da Bodoquena, Galati et al. (2003b), using different animal baits, pointed to pigsties as an important factor of attraction or breeding for this phlebotomine, as it showed greater attraction to pigs than to horses or hens.

Lu. longipalpis was also found in domiciles in town. This fact is a matter of concern for the public health staff because of the insects' great vector ability, its potential for adaptation and dispersion and the confirmation of VL in human (SSMS 2006) and canine (unpublished observation) populations in the municipality of Bela Vista. It is important to note the recent findings of Savani et al. (2005) at Assentamento Guaicurus, located on the western slope of the central part of the Serra da Bodoquena, in which polymerase chain reaction (PCR) showed $L u$. longipalpis females infected with L. amazonensis.

In addition, the presence and breeding of animals in the peridomicile along with poor hygienic conditions may be a factor in the aggregation of Lu. longipalpis as well as of other phlebotomine species, increasing the risk of Leishmania transmission (Forattini 1953, Ximenes et al. 1999).

Though non-significant, the presence of $N y$. whitmani, one of the most important vectors of ACL in the Northeastern, Southeastern, Southern and Mid-Western Regions of Brazil and in Paraguay (Rangel et al. 1990, Hashigushi et al. 1992, Queiroz et al. 1994, Galati et al. 
1996, Dias-Lima et al. 2003, Leonardo \& Rebelo 2004) should be noteworthy. However, the identification of $L$. braziliensis in the cutaneous lesion material of patients from Bela Vista indicates that, even at low densities, this species may present a risk of parasite transmission.

Ps. punctigeniculata, already reported in other areas of MS (Galati et al. 1996, 2006), was practically absent in CDC traps. Nevertheless, its frequency was higher among the females captured with Shannon traps, which reinforces its epidemiological potential as a possible vector of infectious agents to man. Its presence in the white trap only is not in accord with the observations of Galati et al. (2001) in the Serra da Bodoquena, where this species was significantly more attracted to the black trap.

Ps. shannoni was the species most attracted to Shannon traps when considering both sexes and came second among the females. It was found in every month of the study, demonstrating its epidemiological importance as already observed by Galati et al. (1996) in a focus of ACL in the municipality of Corguinho, MS, where it was the second most abundant species in this kind of trap. It was also collected in large numbers when the black trap was used in the Serra da Bodoquena (Galati et al. 2001) and was one of the most prevalent species in this kind of capture in a study performed at Chapada dos Guimarães, Mato Grosso (Biancardi \& Castellón 2000).

This species is widely spread throughout the American continent and, although it is not associated with leishmaniasis transmission, it has been caught in anthropic environments and in captures with human bait (Hashiguchi et al. 1992, Galati et al. 2003b, Balbino et al. 2005). Moreover, it has been regarded as an important transmitter of arbovirus and Endotrypanum schaudinni (Mesnil \& Brimont 1908), a trypanosomatid found only in sloths (Comer et al. 1990, Franco \& Grimaldi 1999). Isoenzyme analysis showed that this species is parasitised by undistinguishable Leishmania flagellates of human origin (Rowton et al. 1991). More recently, Travi et al. (2002) tentatively demonstrated the infection of this species through Leishmania infantuminfected dogs, thus suggesting its participation in the spread of the parasite.

The low attraction to man of Bi. flaviscutellata, a proven vector of $L$. amazonensis in other areas, has been reported in other regions (Lainson 1985, Balbino et al. 2005). The rodent-philic habits of this species were made evident by the captures obtained with Disney traps (Dorval et al. 2007) and in this study the scarcity of specimens caught in Shannon traps $(5.95 \%)$ indirectly showed the species' poor attraction to human bait. This fact could explain the non-occurrence of the disease among the people who visit the area.

The presence of this species in other areas in MS (Oliveira et al. 2003, Galati et al. 2006, Nunes et al. 2008), in spite of the lower number of specimens caught, is epidemiologically relevant, as L. amazonensis has already been reported as an etiological agent of human cases of ACL in the studied area (Dorval et al. 2006). In this context, this species is likely to be involved in the transmission of the disease not only in the study area but also in other areas where it occurs within MS.
Therefore, knowledge about MS's phlebotomine fauna is increasing. Considering the species $L u$. longipalpis, Ny. whitmani and Bi. flaviscutellata, the potential for leishmaniasis transmission and also the fact that the town borders Paraguay and that the movement of people and animals is continuous, the national health surveillance system has to be warned to keep permanent and strict control over the region so as to minimise the spread of these diseases in the state and in the neighbouring country.

\section{ACKNOWLEDGEMENTS}

To the Command and the military of the $10^{\circ} \mathrm{RCMec}$ and to the research team, for the unconditional support to the study, to the Coordenadoria de Controle de Vetores da Secretaria de Estado de Saúde, especially Elias Monteiro, for logistic support, to João Anastácio, for the collaboration in field work, to Militaries André Flávio Maria Zimmermann and Claudemar Borges Dias, for the usual reception and tireless collaboration in the captures.

\section{REFERENCES}

Azevedo ACR, Monteiro FA, Cabello PH, Souza NA, Rosa-Freitas MG, Rangel EF 2000. Studies on populations of Lutzomyia longipalpis (Lutz \& Neiva, 1912) (Diptera: Psychodidae: Phlebotominae) in Brazil. Mem Inst Oswaldo Cruz 95: 305-322.

Balbino VQ, Coutinho-Abreu IV, Sonoda IV, Marques da Silva W, Marcondes 2005. Phlebotomine sandflies (Diptera: Psychodidae) of the Atlantic Forest in Recife, Pernambuco State, Brazil: the species coming to human bait, and their seasonal and monthly variations over a 2-year period. An Trop Med Parasitol 99: 683-693.

Biancardi CMAB, Castellón EG 2000. Flebotomíneos (Diptera: Psychodidae) no estado do Mato Grosso, município de Chapada dos Guimarães, Brasil. Acta Amazonica 30: 115-118.

Comer JA, Tesh RB, Modi GB, Corn JL, Nettles VF 1990. Vesicular stomatitis virus, New Jersey serotype: replication in and transmission by Lutzomyia shannoni (Diptera, Psychodidae). Am J Trop Med Hyg 42: 483-490.

Desjeux P 2004. Leishmaniasis: current situation and new perspectives. Comp Immun Microbiol Infect Dis 27: 305-318.

Dias-Lima AG, Guedes MLS, Sherlock IA 2003. Horizontal stratification of sandfly (Diptera: Psychodidae) in a transitional vegetation between caatinga and tropical rain Forest, state of Bahia, Brazil. Mem Inst Oswaldo Cruz 98: 733-737.

Dorval MEC, Alves TP, Oliveira AG, Brazil RP, Galati EAB, Cunha RV 2007. Modification of Disney trap for capture of sand flies (Diptera: Psychodidae: Phlebotominae). Mem Inst Oswaldo Cruz 102: 877-878.

Dorval MEC, Oshiro ET, Cupollilo E, Camargo ANC, Alves TP 2006. Ocorrência de leishmaniose tegumentar americana no Estado do Mato Grosso do Sul (Brasil) associada à infecção por Leishmania (Leishmania) amazonensis. Rev Soc Bras Med Trop 39: 43-46.

Forattini OP 1953. Nota sobre criadouros naturais de flebótomos em dependências peri-domiciliares, no Estado de São Paulo. Arq Fac Hig Saude Publica Univ Sao Paulo 7: 158-167.

Franco AMR, Grimaldi G 1999. Characterization of Endotrypanum (Kinetoplastida: Trypanosomatidae), a unique parasite infecting the neotropical tree sloths (Edentata). Mem Inst Oswaldo Cruz 94: 261-268.

Galati EAB 2003. Morfologia, terminologia de adultos e identificação dos táxons da América. In EF Rangel, R Lainson, Flebotomíneos do Brasil, Fiocruz, Rio de Janeiro, p. 53-175. 
Galati EAB, Nunes VLB, Boggiani PC, Dorval MEC, Cristaldo G, Rocha HC, Oshiro ET, Damasceno-Júnior GA 2006. Phlebotomines (Diptera: Psychodidae) in forested areas of the Serra da Bodoquena, state of Mato Grosso do Sul, Brazil. Mem Inst Oswaldo Cruz 101: 175-193.

Galati EAB, Nunes VLB, Boggiani PC, Dorval MEC, Cristaldo G, Rocha HC, Oshiro ET, Gonçalves-de-Andrade RM, Naufel G 2003a. Phlebotomines (Diptera, Psychodidae) in caves of the Serra da Bodoquena, Mato Grosso do Sul State, Brazil. Rev Bras Entomol 7: 283-296.

Galati EAB, Nunes VLB, Cristaldo G, Rocha HC 2003b. Aspectos do comportamento da fauna flebotomínea (Diptera: Psychodidae) em foco de leishmaniose visceral e tegumentar na Serra da Bodoquena e área adjacente, Estado de Mato Grosso do Sul, Brasil. Rev Patol Trop 32: 235-261.

Galati EAB, Nunes VLB, Dorval MEC, Cristaldo G, Rocha HC, Gonçalves-Andrade RM, Naufel G 2001. Attraction of black Shannon trap for phlebotomines. Mem Inst Oswaldo Cruz 96: 641-647.

Galati EAB, Nunes VLB, Dorval MEC, Oshiro ET, Cristaldo G, Espíndola MA, Rocha HC, Garcia WB 1996. Estudo dos flebotomíneos (Diptera, Psychodidae) em área de leishmaniose tegumentar, no Estado de Mato Grosso do Sul, Brasil. Rev Saude Publica 30: $115-128$.

Galati EAB, Nunes VLB, Rego Jr FA, Oshiro ET, Chang MR 1997. Estudo de flebotomíneos (Diptera: Psychodidae) em foco de leishmaniose visceral no Estado de Mato Grosso do Sul, Brasil. Rev Saude Publica 31: 378-390.

Haddow AJ 1960. Studies on the biting-habits and medical importance of East African mosquitos in the genus Aedes. I. Subgenera Aedimorphus, Banksinella and Nunnius. Bull Entomol Res 50: 759-779.

Hashiguchi Y, Chiller T, Inchausti A, Arias A, Kawabata M, Alexander JB 1992. Phlebotomine sandfly species in Paraguay and their infection with Leishmania. An Trop Med Parasitol 86: 175-180.

Hayeck LAC, Buzas MA 1997. Surveying natural populations, Columbia University Press, New York, 563 pp.

IBGE - Instituto Brasileiro de Geografia e Estatística 2002. Produção extrativa vegetal, IBGE, Rio de Janeiro, 39 pp.

Lainson R 1985. Our present knowledge of the ecology and control of leishmaniasis in the Amazon Region of Brazil. Rev Soc Bras Med Trop 18: 47-56.

Leonardo FS, Rebelo JMM 2004. A periurbanização de Lutzomyia whitmani em área de foco de leishmaniose cutânea no Estado do Maranhão, Brasil. Rev Soc Bras Med Trop 37: 282-284.

Martins AV, Falcão AL, Williams P 1978. American Sand flies (Diptera: Psychodidae, Phlebotominae), Academia Brasileira de Ciências, Rio de Janeiro, 195 pp.

Martins F, Silva IG, Bezerra WA, Maciel JM, Silva HHG, Lima CG, Cantuária PB, Ramos OS, Ribeiro JB, Santos AS 2002. Diversidade e freqüência da fauna flebotomínea (Diptera: Psychodidae) em áreas com transmissão de leishmaniose no Estado de Goiás. Rev Patol Trop 31: 211-224.

Migone LE 1913. Um caso de kala-azar à Assuncion (Paraguay). Bull Soc Pathol Exot 6: 118-120.
Natal D, Marucci D, Reis IM, Galati EAB 1991. Modificação da armadilha CDC com testes para coletas de flebotomíneos (Diptera). Rev Bras Entomol 35: 697-700.

Nunes VLB 2001. Condicionantes para a transmissão de leishmanioses em assentamento agrícola do INCRA e adjacências, Planalto da Bodoquena, Estado de Mato Grosso do Sul, Brasil, 1998, 1999, $\mathrm{PhD}$ Thesis, Faculdade de Saúde Pública, Universidade de São Paulo, 174 pp.

Nunes VLB, Dorval MEC, Oshiro ET, Arão LB, Hans Filho G, Espíndola MA, Cristaldo G, Rocha HC, Serafini LN, Santos D 1995. Estudo epidemiológico sobre leishmaniose tegumentar (LT) no município de Corguinho, Mato Grosso do Sul. Estudos na população humana. Rev Soc Bras Med Trop 28: 185-193.

Nunes VLB, Galati EAB, Cardozo C, Rocca MEG, Andrade ARO, Santos MFC, Aquino RB, Rosa D 2008. Estudo de flebotomíneos (Diptera, Psychodidae) em área urbana do município de Bonito, Mato Grosso do Sul, Brasil. Rev Bras Entomol 52: 446-451.

Oliveira AG, Andrade-Filho JD, Falcão AL, Brazil RP 2003. Estudo de flebotomíneos (Diptera, Psychodidae, Phlebotominae) na zona urbana da cidade de Campo Grande, Mato Grosso do Sul, Brasil, 1999-2000. Cad Saude Publica 19: 933-944.

Queiroz RG, Vasconcelos IAB, Vasconcelos AW, Pessoa AF, Sousa RN, David JR 1994. Cutaneous leishmaniasis in Ceará State in Northeastern Brazil: incrimination of Lutzomyia whitmani as a vector of Leishmania braziliensis in Baturité municipality. Am J Trop Med Hyg 50: 693-698.

Rangel EF, Lainson R, Souza AA 1990. Lutzomyia (Nyssomyia) whitmani (Antunes \& Coutinho, 1939) (Diptera, Psychodidae, Phlebotominae) a vector of cutaneous eishmaniasis in Brazil. Is it a complex of criptical species? Mem Inst Oswaldo Cruz 85: 122.

Roberts DR, Hsi BP 1979. An index of species abundance for use with mosquito surveillance data. Environ Entomol 8: 1007-1013.

Rowton E, Mata M, Rizzo N, Navin T, Porter C 1991. Vectors of Leishmania braziliensis in the Petén, Guatemala. Parassitologia 33: 501-504.

Savani ESMM, Galati EAB, Nunes VLB, Castilho TM, Camargo COM, D'Auria SRN, Floeter-Winter LM 2005. Natural infection in sand fly vectors in cutaneous and visceral leishmaniasis foci in Mato Grosso do Sul State, Brazil. Proceedings of ISOPS V. Arch Inst Pasteur Tunis 82: 48-49.

SMS - Secretaria Municipal de Saúde, Bela Vista, Mato Grosso do Sul 2001. Plano Municipal de Saúde de Bela Vista, 1997 a 2001, SMS, Bela Vista, 30 pp.

SSMS - Governo do Estado de Mato Grosso do Sul, Secretaria de Saúde do Estado 2006. Serviço de Vigilância Epidemiológica. SINAN/MS. Campo Grande. Available from: http://www.saude. ms.gov.br/index.

Travi BL, Ferro C, Cadena H, Montoya-Lerma J, Adler GH 2002. Canine visceral leishmaniasis: dog infectivity to sand flies from non-endemic areas. Res Vet Sci 72: 83-86.

Ximenes MFFM, Souza MF, Castellón EG 1999. Density of sand flies (Diptera: Psychodidae) in domestic and wild animal shelters in an area of visceral leishmaniasis in the State of Rio Grande do Norte, Brazil. Mem Inst Oswaldo Cruz 94: 427-432. 